\title{
Prevalence, the antibiogram and the frequency of virulence genes of the most predominant bacterial pathogens incriminated in calf pneumonia
}

\author{
Abdelazeem M. Algammal ${ }^{1 *}$ (D), Mahmoud E. El-Sayed ${ }^{1}$, Fatma M. Youssef ${ }^{2}$, Shefaa A. Saad², \\ Mahmoud M. Elhaig ${ }^{3}$, Gaber E. Batiha ${ }^{4}$, Wael N. Hozzein ${ }^{5,6}$ and Madeha O. I. Ghobashy ${ }^{7}$
}

\begin{abstract}
The purpose of this study was to investigate the prevalence, antibiotic resistance and certain virulence genes of the most predominant bacterial pathogens causing BRD. A total of 225 calves; 55 apparently healthy and 170 diseased; were sampled. Bacteriological examination, antimicrobial susceptibility testing and PCR based detection of some virulence genes were performed. In addition, the serotyping of $E$. coli was performed using the slide agglutination test. The most predominant bacterial pathogens retrieved from apparently healthy calves were E. coli (16.4\%) and S. aureus (10.9\%), and in pneumonic calves were E. coli (23.5\%), P. vulgaris (12.4\%) and S. aureus (11.8\%). The most prevalent virulence gene in E. coli was the fimH gene (100\%), followed by eaeA gene (24.5\%) and hly gene (20.4\%). All the examined S. aureus strains harbored spa and coa genes; likewise, all P. multocida strains harbored toxA gene. The majority of the isolated strains displayed remarkable sensitivity to norfloxacin and enrofloxacin; furthermore, the retrieved E. coli strains exhibited multidrug-resistance to gentamicin, erythromycin, streptomycin and trimethoprim-sulphamethoxazole, in addition, the isolated $S$. aureus and $P$. aeruginosa strains showed multidrug-resistance to amoxicillin, ampicillin and tetracycline. E. coli serogroups including $\mathrm{O} 18, \mathrm{O} 143, \mathrm{O} 1$, and $\mathrm{O} 6$ were retrieved from pneumonic calves as the first report in Egypt. In conclusion, the synergism between the conventional and genotypic analysis is an effective gadget for the characterization of bacterial pathogens causing BRD. Continuous surveillance of antimicrobial susceptibility is essential to select the drug of choice due to the development of multidrug-resistant strains.
\end{abstract}

Keywords: BRD, Antibiotic resistance, E. coli, S. aureus, P. multocida, Virulence genes

\section{Introduction}

Bovine respiratory disease (BRD) is one of the major risks to the health of calves and younger cattle, causing significant economic losses (Zeineldin et al. 2017). Viral infections, stresses, nutritional and environmental conditions are leading reasons for the commensal bacteria turned into to be opportunistic pathogens, leading to secondary

\footnotetext{
*Correspondence: abdelazeem.algammal@gmail.com

${ }^{1}$ Department of Bacteriology, Immunology, and Mycology, Faculty of Veterinary Medicine, Suez Canal University, Ismailia 41522, Egypt Full list of author information is available at the end of the article
}

respiratory infections and increase animal susceptibility to the respiratory disease (Clavijo et al. 2007; Griffin et al. 2010). Many bacteria are involved in BRD, including; Staphylococcus aureus, Pasteurella multocida, Escherichia coli, Citrobacter spp., Pseudomonas aeruginosa, Proteus vulgaris, Enterobacter aerogenes, Enterobacter cloacae, Bacillus spp., and Mannheimia haemolytica (de Oliveira et al. 2016; DebRoy et al. 2008; Timsit et al. 2017; Zeineldin et al. 2017).

Clinical signs of BRD vary from acute to chronic illness and include mostly high fever, depression, loss of appetite, cough, rapid respiratory rates, abnormal lung sounds 
and nasal discharge (Radostits et al. 2006). The utilization of antibiotics in the treatment of BRD has widely been reported. The emergence of multidrug-resistant pathogens associated with BRD has been recorded that threatens the livestock industry (Klima et al. 2014). The continuous surveillance of antimicrobial susceptibility should be applied as well as the proper use of antibiotics in order to reduce the spread of multidrug-resistant strains not only between livestock but also to humans (Holman et al. 2015; Klima et al. 2014).

The polymerase chain reaction (PCR) is a highly reliable and specific diagnostic tool that facilitates the detection of pathogens and their virulence genes as well as drug resistance genes (Eid et al. 2016; Enany et al. 2018). Therefore, the current work aimed to determine the prevalence of bacterial pathogens in apparently healthy and pneumonic calves and to monitor the antibiotic susceptibility of the isolated strains, and to perform PCRbased detection of certain virulence genes.

\section{Materials and methods Sampling}

A total of 225 calves, in private cattle farms at the Ismailia governorate, Northern Egypt, were examined for respiratory manifestations from November 2018 to January 2019. The examined calves are ranging in age from one day to 6 months old. All calves were clinically examined calves were categorized into 3 groups, according to the clinical signs, the 1st group $(n=154)$ showed respiratory signs such as fever $\left(>39.5^{\circ} \mathrm{C}\right)$, rapid respiration, coughing, and nasal discharge, the 2nd group $(n=16)$ showed only fever, and the 3rd group (apparently healthy; $n=55$ ) showed no signs. Nasal swabs were gathered from 150 calves that exhibited respiratory signs and from 50 apparently healthy calves. Blood samples were collected in ethylenediaminetetraacetic acid (EDTA) from 16 calves that were showed only fever and from 5 apparently healthy calves. Four samples were collected from lung tissues of 4 emergency slaughtered calves. All specimens were collected and transported to the laboratory for further analysis.

\section{Bacteriological examination}

The collected samples (nasal swabs and homogenized lung tissue) were inoculated into peptone water followed by incubation at $37^{\circ} \mathrm{C}$ for $24 \mathrm{~h}$. A loopful of incubated broth and blood samples were streaked onto Blood agar, Nutrient agar, MacConkey's agar, Eosin methylene blue agar and Mannitol salt agar (Oxoid, UK), and then incubated at $37{ }^{\circ} \mathrm{C}$ for $24-48 \mathrm{~h}$. The characterization of bacterial species was carried out based on the cultural characteristics, Gram's stain, and biochemical reactions according to the previous report (Quinn et al. 2011).

\section{Serotyping of E. coli}

Isolates of $E$. coli were serotyped based upon somatic and flagellar antigens using the slide agglutination test according to the previous report (Edwards and Ewing 1962). It was performed at Animal Health Research Institute, Dokki, Egypt, using a commercially available antisera kit (pathogenic E. coli immune sera) (Denka SeikenCo., Ltd., Tokyo, Japan). Bacteria showing agglutination within $30 \mathrm{~s}$ to antisera were estimated positive for the corresponding serotype.

\section{Pathogenicity test of the isolated $P$. multocida strains}

The P. multocida strains were exposed to the pathogenicity test as the previously described protocol (Varte et al. 2014). Briefly, six mice were $I / P$ inoculated with $100 \mu \mathrm{l}$ of the whole culture; in addition, three mice were inoculated with $100 \mu \mathrm{l}$ of sterile $\mathrm{H}_{2} \mathrm{O}$ (control group). All mice were observed for 2 days. Death within 24-48 h was monitored with postmortem examination. Re-isolation of $P$. multocida from the heart blood of dead mice was carried out by plating on blood agar. In addition, Giemsa stained smears from heart blood were made and microscopically examined. The handling of mice was carried out as described by the Animal Ethics Committee of Suez Canal University, Egypt.

\section{PCR detection of virulence genes}

Genomic DNA of E. coli, S. aureus and P. multocida was extracted according to the manufacturer's instructions of the QIAamp DNA Mini Kit (Catalogue No. 51304). The PCR reactions were done in a $25-\mu \mathrm{l}$ volume containing $5 \mu \mathrm{l}$ of $5 \times$ Master Mix (Jena Bioscience, Germany), $20 \mathrm{pmol}$ of each primer and $3 \mu \mathrm{l}$ of DNA template. Double-distilled $\mathrm{H}_{2} \mathrm{O}$ was added to complete the reaction volume to $25 \mu \mathrm{l}$. Positive controls kindly supplied by Animal Health Research Institute in Dokki, Cairo, Egypt and negative control (no DNA templates) were utilized in all PCRs. The primers sequences (Metabion International AG, Germany) and recycling conditions are listed in Table 1 . The PCR products were separated by electrophoresis $(1.5 \%$ agarose stained with ethidium bromide $0.5 \mu \mathrm{g} / \mathrm{ml}$ ), and the amplicon was captured using a gel documentation system (Biospectrum UVP, UK).

\section{Antimicrobial susceptibility testing}

The antimicrobial susceptibility testing was carried out using the disc diffusion method on Mueller-Hinton agar (Oxoid, UK) according to the previous report (Wayne 2012). Erythromycin $(15 \mu \mathrm{g})$, gentamicin $(10 \mu \mathrm{g})$, tetracycline $(30 \mu \mathrm{g})$, trimethoprim-sulphamethoxazole $(25 \mu \mathrm{g})$, norfloxacin $(10 \mu \mathrm{g})$, enrofloxacin $(5 \mu \mathrm{g})$, streptomycin $(10 \mu \mathrm{g})$, ampicillin $(10 \mu \mathrm{g})$ and amoxicillin $(20 \mu \mathrm{g})$ 
Table 1 Primer sequences and PCR cycling conditions applied for the detection of virulence genes of E. coli, S. aureus and $P$. multocida strains isolated from examined calves

\begin{tabular}{|c|c|c|c|c|c|c|c|}
\hline \multirow[t]{2}{*}{ Bacterial Species } & \multirow[t]{2}{*}{ Target gene } & \multirow[t]{2}{*}{ Primer sequence $\left(5^{\prime}-3^{\prime}\right)$} & \multirow[t]{2}{*}{ Size (bp) } & \multicolumn{3}{|c|}{$\begin{array}{l}\text { PCR cycling conditions } \\
\left.{ }^{\circ} \mathrm{C} / \mathrm{s}\right) \text { for } 35 \text { cycles }\end{array}$} & \multirow[t]{2}{*}{ References } \\
\hline & & & & D & A & $\mathrm{E}$ & \\
\hline \multirow[t]{5}{*}{ E. coli } & $f i m H$ & $\begin{array}{l}\text { TGCAGAACGGATAAGCCGTGG } \\
\text { GCAGTCACCTGCCCTCCGGTA }\end{array}$ & 508 & $94 / 30$ & $50 / 40$ & $72 / 40$ & Ghanbarpour and Salehi (2010) \\
\hline & eaeA & $\begin{array}{l}\text { ATGCTTAGTGCTGGTTTAGG } \\
\text { GCCTTCATCATTTCGCTTTC }\end{array}$ & 248 & $94 / 30$ & $51 / 30$ & $72 / 30$ & Bisi-Johnson et al. (2011) \\
\hline & hly & $\begin{array}{l}\text { AACAAGGATAAGCACTGTTCTGGCT } \\
\text { ACCATATAAGCGGTCATTCCCGTCA }\end{array}$ & 1177 & $94 / 30$ & $60 / 50$ & $72 / 60$ & Piva et al. (2003) \\
\hline & stx 1 & $\begin{array}{l}\text { ACACTGGATGATCTCAGTGG } \\
\text { CTGAATCCCCCTCCATTATG }\end{array}$ & 614 & $94 / 30$ & $58 / 45$ & $72 / 45$ & Dipineto et al. (2006) \\
\hline & stx2 & $\begin{array}{l}\text { CCATGACAACGGACAGCAGTT } \\
\text { CCTGTCAACTGAGCAGCACTTTG }\end{array}$ & 779 & & & & \\
\hline \multirow[t]{2}{*}{ S. aureus } & spa & $\begin{array}{l}\text { TCA ACA AAG AAC AAC AAA ATG C } \\
\text { GCT TTC GGT GCT TGA GAT TC }\end{array}$ & 226 & $94 / 30$ & $5 / 30$ & $72 / 30$ & Wada et al. (2010) \\
\hline & coa & $\begin{array}{l}\text { ATAGAGATGCTGGTA CAGG } \\
\text { GCTTCC GATTGTTCG ATG C }\end{array}$ & 430570630 & $94 / 30$ & $55 / 40$ & $72 / 45$ & Iyerand Kumosani (2011) \\
\hline P. multocida & toxA & $\begin{array}{l}\text { CTTAGATGAGCGACAAGG } \\
\text { GAATGCCACACCTCTATAG }\end{array}$ & 864 & $94 / 30$ & $48 / 45$ & $72 / 45$ & Tang et al. (2009) \\
\hline
\end{tabular}

$D$ denaturation, $A$ annealing, $E$ extension

(Oxford, UK) were used. Results were estimated as described by the Clinical and Laboratory Standards Institute (CLSI 2016).

\section{Statistical analysis}

The Chi square test was used for the analysis of the obtained results using statistical analysis $\left(\mathrm{SAS}^{\circledR}\right.$ software, version 9.4) to test the null hypothesis of various treatments.The significance level was $(p<0.05)$.

\section{Results}

\section{Clinical examination}

The clinical examination revealed pneumonia in calves approaching $68.4 \%$ (154/225), four calves died, and many cases showed mild calf scours. The farm record revealed respiratory infections, mortalities and scours a month prior to sample collection.
Prevalence of bacterial pathogens in apparently healthy and diseased calves

Bacterial pathogens were isolated from $57 \%$ of the examined calves with or without BRD (Table 2). The statistical analysis revealed that there is a significant difference in the prevalence of various pathogens among the examined apparently healthy and pneumonic calves $(p<.05)$. The most prevalent bacterial pathogen isolated from calves with BRD was E. coli (23.5\%), followed by P. vulgaris $(12.4 \%)$ and S. aureus (11.8\%). Moreover, E. coli was the most prevalent bacterium isolated from apparently healthy calves (16.4\%), followed by $S$. aureus (10.9\%) and $P$. vulgaris (5.4\%). In pneumonic calves, $P$. multocida $(\mathrm{n}=3)$ was isolated from lung tissue samples and $M$. haemolytica $(\mathrm{n}=1)$ was isolated from blood samples (Table 3). No bacterial pathogens were detected in the blood samples that were collected from the apparently healthy calves. The bacterial examination yielded 128 isolates (109 from pneumonic calves and 19 from apparently

Table 2 The number and percentage of positive clinical samples using bacterial culture (BC)

\begin{tabular}{|c|c|c|c|c|c|c|c|}
\hline \multirow[t]{2}{*}{ Samples } & \multicolumn{2}{|c|}{ Apparently healthy calves } & \multicolumn{2}{|c|}{ Pneumonic calves } & \multicolumn{2}{|l|}{ Total } & \multirow[t]{2}{*}{$p$-value } \\
\hline & Samples, N & $\begin{array}{l}\text { Positive } \\
\text { samples, N (\%) }\end{array}$ & Samples, N & $\begin{array}{l}\text { Positive } \\
\text { samples, N (\%) }\end{array}$ & Samples, N & $\begin{array}{l}\text { Positive } \\
\text { samples, N (\%) }\end{array}$ & \\
\hline Nasal swabs & 50 & $19(36)$ & 150 & $105(70)$ & 200 & $124(62)$ & \\
\hline Blood samples & 5 & 0 & 16 & $1(6.3)$ & 21 & $1(4.76)$ & $<0.00001^{*}$ \\
\hline Lung tissues (dead) & - & - & 4 & $3(75)$ & 4 & $3(75)$ & \\
\hline Total & 55 & $19(34.5)$ & 170 & $109(64.1)$ & 225 & $128(57)$ & \\
\hline
\end{tabular}

*The result is significant at $p<.05$ 
Table 3 The prevalence of recovered bacterial pathogens from pneumonic and apparently healthy calves

\begin{tabular}{|c|c|c|c|}
\hline Isolates & $\begin{array}{l}\text { Source } \\
\text { of sample }\end{array}$ & No. of isolates (\%) & $p$-value \\
\hline \multicolumn{4}{|c|}{ Pneumonic calves $(n=170)$} \\
\hline E. coli & NS & $40(23.5)$ & $0.000118^{*}$ \\
\hline P. vulgaris & NS & $21(12.4)$ & \\
\hline S. aureus & NS & $20(11.8)$ & \\
\hline$P$. aeruginosa & NS & $10(5.9)$ & \\
\hline E. cloacae & NS & $7(4.1)$ & \\
\hline P. multocida & LT & $3(1.8)$ & \\
\hline E. aerogenes & NS & $7(4.1)$ & \\
\hline M. haemolytica & BS & $1(0.6)$ & \\
\hline Total & & $109(64.1)$ & \\
\hline \multicolumn{4}{|c|}{ Apparently healthy calves $(n=55)$} \\
\hline E. coli & NS & $9(16.4)$ & \\
\hline S. aureus & NS & $6(10.9)$ & \\
\hline P. vulgaris & NS & $3(5.4)$ & \\
\hline E. aerogenes & NS & $1(1.8)$ & \\
\hline Total & & $19(34.5)$ & \\
\hline
\end{tabular}

NS nasal swab, $L T$ lung tissue, $B S$ blood sample

*The result is significant at $p<.05$

Table 4 The frequency of mixed infection in the examined samples

\begin{tabular}{ll}
\hline Mixed isolates & Samples* $(\boldsymbol{n}$, type $)$ \\
\hline Pneumonic calves & \\
E. coli + E. cloacae & $5(\mathrm{NS})$ \\
E. coli E. aerogenes & $5(\mathrm{NS})$ \\
S.aureus + Proteus vulgaris & $6(\mathrm{NS})$ \\
Apparently healthy calves & \\
E. coli + E. aerogenes & $1(\mathrm{NS})$ \\
Total & $17(7.6 \%)$ \\
\hline
\end{tabular}

*Total number of samples (cases) $=225$

healthy calves). Moreover, 17 samples (7.6\%) presenting a combination of two bacterial pathogens (mixed infection) (Table 4).

\section{Serotyping of the isolated $E$. coli isolates}

The isolated $E$. coli $(\mathrm{n}=49)$ strains were examined serologically with $\mathrm{O}$ and $\mathrm{H}$ antisera. As described in Table 5, the serological analysis of revealed 8 serogroups in pneumonic calves; O18:H6 $(\mathrm{n}=5), \mathrm{O} 119: \mathrm{H} 4(\mathrm{n}=4), \mathrm{O} 86: \mathrm{H} 9$ $(\mathrm{n}=5), \quad \mathrm{O} 158: \mathrm{H} 10 \quad(\mathrm{n}=4), \quad \mathrm{O} 143: \mathrm{H} 4 \quad(\mathrm{n}=8), \mathrm{O} 1: \mathrm{H} 2$ $(\mathrm{n}=4), \mathrm{O} 63: \mathrm{H} 7(\mathrm{n}=6)$ and O128:H2 $(\mathrm{n}=4)$, and 3 serogroups in apparently healthy calves; O18:H6 $(\mathrm{n}=4)$, O86:H9 $(n=3)$, O63:H7 $(n=2)$. The statistical analysis proved that there is no significant difference in the types
Table 5 The distribution of E. coli Serotypes in examined pneumonic and apparently healthy calves

\begin{tabular}{lccc}
\hline $\begin{array}{l}\text { Serotypes of } E \text {. coli } \\
(\mathbf{n}=\mathbf{4 9 )}\end{array}$ & Pneumonic calves & Healthy calves & $\boldsymbol{p}$-value \\
\hline O18:H6 & 5 & 4 & $0.2^{\mathrm{NS}}$ \\
O119:H4 & 4 & - & \\
O86:H9 & 5 & 3 & \\
O158:H10 & 4 & - & \\
O143:H4 & 8 & - & \\
O1:H2 & 4 & - & \\
O63:H7 & 6 & 2 & \\
O128:H2 & 4 & - & \\
Total & 40 & 9 &
\end{tabular}

NS: The result is non-significant at $p<.05$

Table 6 The prevalence of virulence genes among E. coli, S.aureus and $P$. multocida strains isolated from calves

\begin{tabular}{lll}
\hline Bacterial species $(\mathbf{n})$ & Target gene & PCR positive, N (\%) \\
\hline E. coli $(n=49)$ & fimH & $49(100)$ \\
& eaeA & $12(24.5)$ \\
& hly & $10(20.4)$ \\
& stx1 & 0 \\
S. aureus $(n=26)$ & stx2 & 0 \\
P. multocida $(n=3)$ & coa & $26(100)$ \\
& toxA & $26(100)$
\end{tabular}

of the $\mathrm{O}$ antigens of $E$. coli isolated from healthy calves and pneumonic calves $(p>0.05)$.

Pathogenicity test for $P$. multocida isolates

All the isolates of $P$. multocida killed all the tested mice $(\mathrm{n}=6) 24 \mathrm{~h}$ after the inoculation. The postmortem examination showed generalized septicemia with congestion at subcutaneous tissues and internal organs. The stained smears from heart blood showed the characteristic bipolar pattern of $P$. multocida.

\section{PCR detection of virulence genes}

As illustrated in Table 6, the fim $\mathrm{H}$, eae A and hly genes were detected in $100 \%, 24.5 \%$ and $20.4 \%$ of the isolated $E$. coli strains $(\mathrm{n}=49)$, respectively. However, stx 1 and st $x 2$ genes were not detected in the tested $E$. coli strains. Furthermore, all the examined $S$. aureus strains $(\mathrm{n}=26)$ harbored both spa and coa genes (100\% each). Additionally, the toxA gene was detected in all the tested P. multocida strains. 
Antimicrobial susceptibility testing

As illustrated in Tables 7 and 8, all the isolated E. coli strains were sensitive to enrofloxacin and norfloxacin ( $90 \%$ for each). Moreover, they exhibited multidrugresistance against gentamicin (90\%), erythromycin, streptomycin (80\% for each) and trimethoprim-sulphamethoxazole (70\%). Furthermore, the examined $S$. aureus strains showed remarkable sensitivity to enrofloxacin (90\%), erythromycin, norfloxacin (80\% for each) and gentamicin (70\%), while showed multi-drug resistance pattern against amoxicillin, ampicillin $(100 \%$ for each) and tetracycline (70\%). In addition, all the examined $P$. aeruginosa strains were sensitive to enrofloxacin, norfloxacin and gentamicin, while showed multidrug-resistance against erythromycin, amoxicillin, ampicillin (100\% for each) and tetracycline (80\%). Regarding $P$. multocia, all the tested isolates were sensitive to gentamicin, enrofloxacin, and norfloxacin, while exhibited multidrug resistance against ampicillin, amoxicillin, erythromycin, and streptomycin $(100 \%$ for each).

\section{Discussion}

This cross-sectional study analyzed the bacterial pathogens in healthy and pneumonic calves and provided a comprehensive analysis of the dominant bacterial pathogens causing respiratory infections in calves. The prevalence of causes of respiratory disease is highly changing within the cases and depends on various factors that affect the detected pathogens (Klima et al. 2014). Overall, the prevalence of bacterial pathogens in this study was $57 \%$, comprising $62 \%$ of nasal swabs, $4.76 \%$ of blood samples and $75 \%$ of lung tissue (Table 2). These findings proved that the nasopharyngeal tract is a common habitat of opportunistic bacteria as well as the portal of entry of pathogenic infectious agents, which is endorsed by Holman et al. (Holman et al. 2015).

The most frequent bacterial pathogens isolated from the respiratory tract of apparently healthy calves were E. coli, followed by $S$. aureus, while in pneumonic calves were E. coli, $P$. vulgaris and $S$. aureus, these findings agree with previous studies characterizing the Proteobacteria in the nasopharyngeal tract of different animals (Holman et al. 2015; Ouchriah et al. 2015). Although de Oliveira et al. (de Oliveira et al. 2016) had isolated E. coli in a low proportion (4.22\%) from healthy and diseased animals

Table 7 In-Vitro antimicrobial susceptibility of the isolated bacterial pathogens from pneumonic calves

\begin{tabular}{|c|c|c|c|c|c|c|c|c|c|c|c|c|c|}
\hline \multirow[t]{2}{*}{ Antimicrobial agent } & \multirow[t]{2}{*}{ Disc conc. $(\mu \mathrm{g})$} & \multicolumn{3}{|c|}{$\begin{array}{l}\text { E. coli (\%) } \\
\mathrm{N}=40\end{array}$} & \multicolumn{3}{|c|}{$\begin{array}{l}\text { S. aureus (\%) } \\
\mathrm{N}=20\end{array}$} & \multicolumn{3}{|c|}{$\begin{array}{l}\begin{array}{l}P . \text { aeruginosa }(\%) \\
\mathrm{N}=10\end{array} \\
\end{array}$} & \multicolumn{3}{|c|}{$\begin{array}{l}\text { P. multocida (\%) } \\
\mathrm{N}=3\end{array}$} \\
\hline & & $\mathbf{R}$ & 1 & $\mathrm{~S}$ & $R$ & $\mathrm{I}$ & $\mathrm{S}$ & $\mathbf{R}$ & $\mathrm{I}$ & $S$ & $R$ & $\mathrm{I}$ & $S$ \\
\hline Ampicillin & 10 & 20 & 50 & 30 & 100 & 0 & 0 & 100 & 0 & 0 & 100 & 0 & 0 \\
\hline Amoxicillin & 20 & 30 & 30 & 40 & 100 & 0 & 0 & 100 & 0 & 0 & 100 & 0 & 0 \\
\hline Erythromycin & 15 & 80 & 20 & 0 & 20 & 0 & 80 & 100 & 0 & 0 & 100 & 0 & 0 \\
\hline Enrofloxacin & 5 & 0 & 10 & 90 & 0 & 10 & 90 & 0 & 0 & 100 & 0 & 0 & 100 \\
\hline Gentamicin & 10 & 90 & 10 & 0 & 20 & 10 & 70 & 0 & 0 & 100 & 0 & 0 & 100 \\
\hline Norfloxacin & 10 & 0 & 10 & 90 & 10 & 10 & 80 & 0 & 0 & 100 & 0 & 0 & 100 \\
\hline Streptomycin & 10 & 80 & 10 & 10 & 50 & 40 & 10 & 20 & 20 & 60 & 100 & 0 & 0 \\
\hline Tetracycline & 30 & 40 & 20 & 40 & 70 & 10 & 20 & 80 & 20 & 0 & 0 & 33 & 67 \\
\hline Trimethoprim-Sulphamethoxazol & 25 & 70 & 10 & 20 & 30 & 20 & 50 & 20 & 40 & 40 & 67 & 0 & 33 \\
\hline
\end{tabular}

Disc conc. disc concentration, $S$ sensitive, I intermediate, $R$ resistant

Table 8 The multidrug-resistance patterns of the isolated bacterial pathogens from pneumonic calves

\begin{tabular}{lcccc}
\hline Antimicrobial agent & E. coli $(\mathbf{N}=\mathbf{4 0}), \mathbf{N}(\%)$ & S. aureus $(\mathbf{N}=\mathbf{2 0}), \mathbf{N}(\%)$ & $\begin{array}{l}\text { P. aeruginosa }(\mathbf{N}=\mathbf{1 0}), \mathbf{N} \\
(\%)\end{array}$ & $\begin{array}{l}\text { P. multocida } \\
(\mathbf{N}=3), \mathbf{N}(\%)\end{array}$ \\
\hline Ampicillin & & & $10(100 \%)$ & $3(100 \%)$ \\
Amoxicillin & $8(20 \%)$ & $20(100 \%)$ & $10(100 \%)$ & $3(100 \%)$ \\
Erythromycin & $12(30 \%)$ & $20(100 \%)$ & $10(100 \%)$ & $3(100 \%)$ \\
Gentamicin & $32(80 \%)$ & $4(20 \%)$ & - & - \\
Streptomycin & $36(90 \%)$ & $4(20 \%)$ & $2(20 \%)$ & $3(100 \%)$ \\
Tetracycline & $32(80 \%)$ & $10(50 \%)$ & $8(80 \%)$ & - \\
Trimethoprim-Sulphamethoxazol & $16(40 \%)$ & $14(70 \%)$ & $2(20 \%)$ & $2(67 \%)$ \\
\hline
\end{tabular}


with respiratory signs, another report indicated the significance of $E$. coli in bronchopneumonia (DebRoy et al. 2008). The comparatively high proportion of $E$. coli in the study is worthwhile and of epidemiological importance. These findings suggest that these calves are likely to have originated from several farms and have a poor treatment and a negative immune deficiency and calls further characterization of more strains that will contribute to controlling the problem in local and/or international areas.

The bacterial variety of the bovine nasopharyngeal tract was much low when compared to other sites in the body (Holman et al. 2015). However, considerable different bacteria were observed in the present study from the nasal cavity of pneumonic calves greater than healthy calves as shown in Table 3, similar to previous reports (Angen et al. 2009; Clavijo et al. 2007; Ouchriah et al. 2015). Further, the finding of different bacterial pathogens in calves with pneumonia in this study supports the multifactorial causes of BRD in calves (Angen et al. 2009; Szeredi et al. 2010). A previous study revealed considerable variations in bacterial pathogens between healthy and diseased calves (Zeineldin et al. 2017).

In the current study, the E. coli serotyping revealed the serogroups; O86, O119, and O158, which were also demonstrated in diarrheic calves from Egypt by a previous report (Hakim et al. 2017). The serogroups; O18, O143, O1and $\mathrm{O} 63$ are specified in our survey and had a different variety than previous studies (Hakim et al. 2017; Vu-Khac and Cornick 2008), and to the best of our knowledge, this is the first report of these serogroups $(\mathrm{O} 18, \mathrm{O} 143, \mathrm{O} 1$, and $\mathrm{O} 63)$ in E. coli strains identified from pneumonic calves in Egypt. Further, most $E$. coli strains isolated from healthy and pneumonic calves carry one to three virulence genes; fim $\mathrm{H}$, eaeA and $h l y$. However, st $x 1$ and $s t \times 2$ genes were not detected, in agreement with a previous study (Osman et al. 2013). Extraintestinal $E$. coli carried many virulent genes that have been detected in bronchopneumonia in horse (DebRoy et al. 2008). These findings showed that all $E$. coli strains isolated in the current study from nasal secretions of pneumonic calves are being pathogenic and may play a role in the epidemiology of BRD either alone or in combination with other pathogens. Also, S. aureus is one of the most common identified bacterial pathogens isolated from healthy and pneumonic calves (Table 3). All examined $S$. aureus strains harbored both spa and coa virulence genes. The proportion of $S$. aureus isolation in this study was higher than reported in calves (1.4\%) from Brazil (Gaeta et al. 2018). This variation may be due to the difference in hygienic measures, farm management, and exposure to stress. Calves can inhale many environmental bacteria and can detect those bacteria in both the upper and lower respiratory systems, and therefore their opportunistic role should be looked (Gaeta et al. 2018; Griffin et al. 2010).

Although P. multocida is a significant agent of BRD (Griffin et al. 2010), in the current study, lower prevalence $(1.8 \%)$ of $P$. multocida was recorded in diseased calves when compared to a prior report (5.5\%) described by de Oliveira et al. (de Oliveira et al. 2016). A previous study indicated that $P$. multocida is frequently isolated from calves with pneumonia, which has previously been exposed to environmental and stress factors (Dabo et al. 2007). In addition, the virulence of $P$. multocida was confirmed in this study, where all tested mice have died $24 \mathrm{~h}$ later, which agrees with the results obtained by Okerman et al. (Okerman et al. 1979). Further, the toxA gene is a virulence gene associated with $P$. multocida, was identified by PCR in all isolates. A previous investigation reported that PCR targeting tox $A$ gene is sensitive and essential for the detection of pathogenic $P$. multocida (Varte et al. 2014).

Moreover, P. aeruginosa, E. cloacae, E. aerogenes, and $M$. haemolytica were detected (Table 3 ) more frequently from diseased calves compared to the healthy calves. Previous studies recovered Bacillus species, Klebsiella species and $P$. aeruginosa in calves with bronchopneumonia (de Oliveira et al. 2016). Regarding pathogens, some species that are not of obvious importance associated with pneumonia, but their opportunistic role should not be ignored (Griffin et al. 2010).

Regarding the antibiogram of the most predominant isolates, as shown in Tables 7 and 8, most of the isolated E. coli, S. aureus, $P$. multocida and $P$. aeruginosa strains were highly sensitive to enrofloxacin and norfloxacin and showed variable degrees of resistance against the rest of the tested antimicrobial agents. The high sensitivity of enrofloxacin and norfloxacin is supported by previous reports (Kroemer et al. 2012; Kumar et al. 2009) and suggests that these antibiotics can still be utilized with a high chance of curative success for the treatment of respiratory diseases in bovines. Furthermore, the finding of high effectiveness of gentamicin against $P$. multocida is in contrast with a previous study on veal calves (Catry et al. 2005), who found that $P$. multocida was gentamicinresistant. The multidrug-resistance was observed among the majority of the isolated $S$. aureus, $P$. multocida and $P$. aeruginosa strains against 3-4 antimicrobial agents, while most of $E$. coli strains were resistant to 4 antimicrobial agents, and could be attributed to the random use of antibiotics over time in animal production (Haftu et al. 2012) and of clinical significance, particularly in the calves industry system. Previous studies from Ethiopia, Brazil, Belgium, Egypt, and Canada have indicated that there is a remarkable increase in the prevalence of multidrugresistant E. coli, S. aureus and P. multocida strains (Catry 
et al. 2016; Eid et al. 2019; Enany et al. 2019; Haftu et al. 2012; Timsit et al. 2017, Algammal et al. 2020).

In conclusion, the current findings described the bacterial causes of BRD in nasal swabs, blood samples, and lung tissues obtained from apparently healthy and diseased calves. E. coli and S. aureus were the most predominant bacterial pathogens incriminated in BRD. The lower prevalence of important pathogens like $P$. multocida may indicate the possible role of other types of opportunistic bacteria in BRD. To the best of our knowledge, E. coli serogroups; O18, O143, O1, and O63 were identified in cases of calf pneumonia as the first report in Egypt. Continuous surveillance of antimicrobial susceptibility is essential to select the drug of choice due to the development of multidrug-resistant strains. Enrofloxacin and norfloxacin were the most effective antimicrobials against calf respiratory pathogens. The application of both phenotypic and genotypic analyses is more valuable as a diagnostic tool for identifying the causes and could help in the proper treatment of BRD.

\section{Acknowledgements}

The authors are grateful to the Researchers Supporting Project number (RSP2019/53), King Saud University, Riyadh, Saudi Arabia.

\section{Authors' contributions}

AMA, MEE Designed the study; AMA, FMY, and SAS Methodology; AMA, MME, MOIG, GEB, and WNH Data analysis and statistical analysis; AMA and MME Writing, Review \& Editing. All authors have agreed to the published version of the manuscript. All authors read and approved the final manuscript.

\section{Availability of data and materials \\ Not applicable.}

\section{Ethics approval and consent to participate}

Handling of animals was conducted as described by the Animal Ethics Committee of Suez Canal University, Egypt.

\section{Consent for publication}

All authors gave their informed consent prior to their inclusion in the study.

\section{Competing interests}

The authors declare that they have no competing interests.

\section{Author details}

1 Department of Bacteriology, Immunology, and Mycology, Faculty of Veterinary Medicine, Suez Canal University, Ismailia 41522, Egypt. ${ }^{2}$ Department of Clinical Pathology, Animal Health Research Institute, Ismailia 41522, Egypt. ${ }^{3}$ Department of Animal Medicine (Infectious Diseases), Faculty of Veterinary Medicine, Suez Canal University, Ismailia 41522, Egypt. ${ }^{4}$ Department of Pharmacology and Therapeutics, Faculty of Veterinary Medicine, Damanhour University, Damanhour 2251, Egypt. ${ }^{5}$ Bioproducts Research Chair, Zoology Department, College of Science, King Saud University, Riyadh 11451, Saudi Arabia. ${ }^{6}$ Botany and Microbiology Department, Faculty of Science, Beni-Suef University, Beni Suef 62511, Egypt. ${ }^{7}$ Microbiology Department, Faculty of Science, Ain Shams University, Cairo, Egypt.

Received: 12 March 2020 Accepted: 23 May 2020

Published online: 29 May 2020

\section{References}

Algammal AM, Enany ME, El-Tarabili RM, Ghobashy MOI, Helmy YA (2020) Prevalence, antimicrobial resistance profiles, virulence and enterotoxindeterminant genes of MRSA isolated from subclinical Bovine Mastitis in Egypt. Pathogens 9(5):E362. https://doi.org/10.3390/pathogens9 050362

Angen $\varnothing$, Thomsen J, Larsen LE, Larsen J, Kokotovic B, Heegaard PM, Enemark JM (2009) Respiratory disease in calves: microbiological investigations on trans-tracheally aspirated bronchoalveolar fluid and acute phase protein response. Vet Microbiol 137:165-171

Bisi-Johnson MA, Obi CL, Vasaikar SD, Baba KA, Hattori T (2011) Molecular basis of virulence in clinical isolates of Escherichia coli and Salmonella species from a tertiary hospital in the Eastern Cape, South Africa. Gut Pathog 3:9

Catry B, Haesebrouck F, Vliegher SD, Feyen B, Vanrobaeys M, Opsomer G, Schwarz S, Kruif AD (2005) Variability in acquired resistance of Pasteurella and Mannheimia isolates from the nasopharynx of calves, with particular reference to different herd types. Microb drug resist 11:387-394

Catry B, Dewulf J, Maes D, Pardon B, Callens B, Vanrobaeys M, Opsomer G, de Kruif A, Haesebrouck F (2016) Effect of antimicrobial consumption and production type on antibacterial resistance in the bovine respiratory and digestive tract. PLOS ONE 11:e0146488

Clavijo A, Alfaro C, de Rolo M (2007) Ecología bacteriana relacionada con problemas respiratorios en terneros del estado Monagas. Zootec trop 25:197-200

CLSI (2016) Performance standards for antimicrobial susceptibility testing, vol 26. Clinical Lab Standards Institute, Wayne, PA, USA, pp 1-251

Dabo S, Taylor J, Confer A (2007) Pasteurella multocida and bovine respiratory disease. Anim Health Res Rev 8:129-150

de Oliveira BAFD, Gaeta NC, Ribeiro BLM, Alemán MAR, Marques LM, Timenetsky J, Melville PA, Marques JA, Marvulle V, Gregory L (2016) Determination of bacterial aetiologic factor on tracheobronchial lavage in relation to clinical signs of bovine respiratory disease. J Med Microbiol 65:1137-1142

DebRoy C, Roberts E, Jayarao BM, Brooks JW (2008) Bronchopneumonia associated with extraintestinal pathogenic Escherichia coli in a horse. J Vet Diagn Investig 20:661-664

Dipineto L, Santaniello A, Fontanella M, Lagos K, Fioretti A, Menna L (2006) Presence of Shiga toxin-producing Escherichia coli O157: H7 in living layer hens. Lett Appl Microbiol 43:293-295

Edwards PR, Ewing WH (1962) Identification of Enterobacteriaceae Identification of Enterobacteriaceae, 3rd Edition

Eid HI, Algammal AM, Nasef SA, Elfeil WK, Mansour GH (2016) Genetic variation among avian pathogenic $E$. coli strains isolated from broiler chickens. AJAVA 11:350-356

Eid HM, Algammal AM, Elfeil WK, Youssef FM, Harb SM, Abd-Allah EM (2019) Prevalence, molecular typing, and antimicrobial resistance of bacterial pathogens isolated from ducks. Vet World 12:677

Enany ME, Algammal AM, Shagar GI, Hanora AM, Elfeil WK, Elshaffy NM (2018) Molecular typing and evaluation of Sidr honey inhibitory effect on virulence genes of MRSA strains isolated from catfish in Egypt. Pak J Pharm Sci 31:1865

Enany ME, Algammal AM, Nasef SA, Abo-Eillil SA, Bin-Jumah M, Taha AE, Allam AA (2019) The occurrence of the multidrug resistance (MDR) and the prevalence of virulence genes and QACs resistance genes in E. coli isolated from environmental and avian sources. AMB Express 9:192

Gaeta NC, Ribeiro BL, Alemán MA, Yoshihara E, Nassar AF, Marques LM, Timenetsky J, Gregory L (2018) Bacterial pathogens of the lower respiratory tract of calves from Brazilian rural settlement herds and their association with clinical signs of bovine respiratory disease. Pesq Vet Bras 38:374-381

Ghanbarpour R, Salehi M (2010) Determination of adhesin encoding genes in Escherichia coli isolates from omphalitis of chicks. Am J Anim Vet Sci 5:91-96

Griffin D, Chengappa M, Kuszak J, McVey DS (2010) Bacterial pathogens of the bovine respiratory disease complex. Vet Clin N AM-Food A 26:381-394

Haftu R, Taddele H, Gugsa G, Kalayou S (2012) Prevalence, bacterial causes, and antimicrobial susceptibility profile of mastitis isolates from cows in large-scale dairy farms of Northern Ethiopia. Trop Anim Health Pro 44:1765-1771

Hakim AS, Omara ST, Syame SM, Fouad EA (2017) Serotyping, antibiotic susceptibility, and virulence genes screening of Escherichia coli isolates 
obtained from diarrheic buffalo calves in Egyptian farms. Vet World 10:769

Holman DB, Timsit E, Alexander TW (2015) The nasopharyngeal microbiota of feedlot cattle. Sci Rep 5:15557

lyer AP, Kumosani TA PCR based detection of nosocomial infection causing MRSA (Methicillin resistant Staphylococcus aureus). In: 2nd International Conference on Biotechnology and Food Science IPCBEE, 2011

Klima CL, Zaheer R, Cook SR, Booker CW, Hendrick S, Alexander TW, McAllister TA (2014) Pathogens of bovine respiratory disease in North American feedlots conferring multidrug resistance via integrative conjugative elements. J Clin Microbiol 52:438-448

Kroemer S, Galland D, Guérin-Faublée V, Giboin H, Woehrlé-Fontaine F (2012) Survey of marbofloxacin susceptibility of bacteria isolated from cattle with respiratory disease and mastitis in Europe. Vet Rec 170:53

Kumar P, Singh V, Agrawal R, Singh S (2009) Identification of Pasteurella multocida isolates of ruminant origin using polymerase chain reaction and their antibiogram study. Trop Anim Health Pro 41:573-578

Okerman L, Spanoghe L, De Bruycker RM (1979) Experimental infections of mice with Pasteurella multocida strains isolated from rabbits. J Comp Pathol 89:51-55. https://doi.org/10.1016/0021-9975(79)90008-2

Osman K, Mustafa A, Elhariri M, Abdelhamed G (2013) The distribution of Escherichia coli serovars, virulence genes, gene association and combinations and virulence genes encoding serotypes in pathogenic E. coli recovered from diarrhoeic calves, sheep and goat. Transbound Emerg Dis 60:69-78

Ouchriah Y, Heleili N, Mamache B, Ayachi A, Kassah AL (2015) Antimicrobial sensitivity of bacterial strains isolated from new-born calves in the abattoir of Batna (Algeria). Int J Livest Res 5:32-42

Piva IC, Pereira AL, Ferraz LR, Silva RS, Vieira AC, Blanco JE, Blanco M, Blanco J, Giugliano LG (2003) Virulence markers of enteroaggregative Escherichia coli isolated from children and adults with diarrhea in Brasilia, Brazil. J Clin Microbiol 41:1827-1832

Quinn PJ, Markey BK, Leonard FC, Hartigan P, Fanning S, FitzPatrick E (2011) Veterinary microbiology and microbial disease. Wiley, Hoboken

Radostits OM, Gay CC, Hinchcliff KW, Constable PD (2006) Veterinary medicine e-book: a textbook of the diseases of cattle, horses, sheep, pigs and goats. Elsevier, Amsterdam
Szeredi L, Jánosi S, Pálfi V (2010) Microbiological and pathological examination of fatal calf pneumonia cases induced by bacterial and viral respiratory pathogens. Acta Vet Hung 58:341-356

Tang X, Zhao Z, Hu J, Wu B, Cai X, He Q, Chen H (2009) Isolation, antimicrobial resistance, and virulence genes of Pasteurella multocida strains from swine in China. J Clin Microbiol 47:951-958

Timsit E, Hallewell J, Booker C, Tison N, Amat S, Alexander TW (2017) Prevalence and antimicrobial susceptibility of Mannheimia haemolytica, Pasteurella multocida, and Histophilus somni isolated from the lower respiratory tract of healthy feedlot cattle and those diagnosed with bovine respiratory disease. Vet Microbiol 208:118-125

Varte Z, Dutta T, Roychoudhury P, Begum J, Chandra R (2014) Isolation, identification, characterization and antibiogram of Pasteurella multocida isolated from pigs in Mizoram with special reference to progressive atrophic rhinitis. Vet World 7:95-99

Vu-Khac H, Cornick NA (2008) Prevalence and genetic profiles of Shiga toxinproducing Escherichia coli strains isolated from buffaloes, cattle, and goats in central Vietnam. Vet Microbiol 126:356-363

Wada M, Lkhagvadorj E, Bian L, Wang C, Chiba Y, Nagata S, Shimizu T, Yamashiro Y, Asahara T, Nomoto K (2010) Quantitative reverse transcriptionPCR assay for the rapid detection of methicillin-resistant Staphylococcus aureus. J Appl Microbiol 108:779-788

Wayne P (2012) Clinical and Laboratory Standards Institute (CLSI) Performance standards for antimicrobial susceptibility testing Twenty-second informational supplement M100-S21 United States, Wayne

Zeineldin M, Lowe J, de Godoy M, Maradiaga N, Ramirez C, Ghanem M, ElRaof YA, Aldridge B (2017) Disparity in the nasopharyngeal microbiota between healthy cattle on feed, at entry processing and with respiratory disease. Vet Microbiol 208:30-37

\section{Publisher's Note}

Springer Nature remains neutral with regard to jurisdictional claims in published maps and institutional affiliations.

\section{Submit your manuscript to a SpringerOpen ${ }^{\circ}$ journal and benefit from:}

- Convenient online submission

- Rigorous peer review

- Open access: articles freely available online

- High visibility within the field

- Retaining the copyright to your article

Submit your next manuscript at $\boldsymbol{\nabla}$ springeropen.com 